\title{
A Rare Co-Occurrence of Parathyroid and Papillary Thyroid Carcinoma
}

\author{
Neslihan Soysal-Atile \\ Tekirdağ State Hospital, Endocrinology \\ Department, Tekirdağ, Turkey \\ soysaln@yahoo.com \\ Ebru Taştekin \\ Trakya University Faculty of Medicine, \\ Pathology Department, Edirne, Turkey \\ ebrutastekin@hotmail.com
}

Atakan Sezer

Trakya University Faculty of Medicine, General Surgery Department, Edirne, Turkey atakansezer@hotmail.com

\author{
Sibel Güldiken \\ Trakya University Faculty of Medicine, \\ Endocrinology Department, Edirne, Turkey \\ sibelguldiken71@hotmail.com \\ Hüseyin Çelik \\ Trakya University Faculty of Medicine, \\ Endocrinology Department, Edirne, Turkey \\ drhuseyincelik@hotmail.com \\ Nermin Tunçbilek \\ Trakya University Faculty of Medicine, \\ Radiology Department, Edirne, Turkey \\ drtuncbilek@hotmail.com
}

\section{Armağan Tuğrul}

Trakya University Faculty of Medicine, Endocrinology Department, Edirne, Turkey aatugrul@yahoo.co.uk

\begin{abstract}
:
Introduction: Although co-occurring thyroid pathologies are common in patients with primary hyperparathyroidism, synchronous parathyroid and differentiated thyroid carcinoma is a rare situation.

Case: A 65-year-old woman presented to our endocrinology clinic for evaluation of hypercalcemia. She had an albumin-corrected serum calcium (Ca) concentration of $12.4 \mathrm{mg} / \mathrm{dl}$ (normal, 8.6-10 mg/dl), serum phosphorus $(P)$ concentration of $2.2 \mathrm{mg} / \mathrm{dl}$ (normal, $2.4-5.1 \mathrm{mg} / \mathrm{dl}$ ), and intact parathyroid hormone (iPTH) concentration of $437 \mathrm{pg} / \mathrm{ml}$ (normal, $12-88 \mathrm{pg} / \mathrm{ml}$ ). Ultrasound revealed thyroid nodules and a parathyroid adenoma. Histopathology showed a parathyroid carcinoma in the left lower parathyroid gland and a co-occurring multifocal papillary carcinoma on both sides of the thyroid gland.

Conclusion: Here we describe a patient with synchronous parathyroid carcinoma and papillary thyroid carcinoma. Thyroid lesions, including differentiated cancers, may occur together with parathyroid lesions, suggesting the need to evaluate the thyroid gland in patients with primary hyperparathyroidism.
\end{abstract}

Keywords: parathyroid carcinoma; thyroid papillary carcinoma; fine needle aspiration cytology; MIBI

\section{INTRODUCTION}

Parathyroid carcinoma (PC) is an uncommon malignancy and a rare cause of primary hyperparathyroidism (PHPT), with an estimated incidence of 5.73 per 10 million people [1]. The main cause of PHPT is parathyroid adenoma or primary parathyroid hyperplasia, with PC causing PHPT in only $1 \%$ of patients [2]. The clinical and biochemical characteristics of parathyroid adenoma and carcinoma are similar, making a specific diagnosis difficult to establish.

Several recent studies and case reports have suggested the co-occurrence of several parathyroid and thyroid disorders, with most showing that parathyroid adenomas occur frequently in patients with differentiated thyroid carcinoma. Here we describe a patient with PC and papillary thyroid carcinoma (PTC), which co-occur rarely, and review the literature on this subject.

\section{CASE REPORT}

A 65-year-old woman was admitted to our hospital for routine control for hypertension. On clinical examination, a non-tender mass of $2 \mathrm{~cm}$ was palpated on the left side of the neck. Laboratory 
investigations revealed an albumin-corrected serum calcium $(\mathrm{Ca})$ concentration of $12.4 \mathrm{mg} / \mathrm{dl}$ (normal, 8.6-10 mg/dl), a serum phosphorus (P) concentration of $2.2 \mathrm{mg} / \mathrm{dl}$ (normal, 2.4-5.1 mg/dl), and an intact parathyroid hormone (iPTH) concentration of $437 \mathrm{pg} / \mathrm{ml}$ (normal, $12-88 \mathrm{pg} / \mathrm{ml}$ ). Free thyroxine (FT4; $0.84 \mathrm{ng} / \mathrm{dl}$ [normal, 0.8-1.58 ng/dl]), triiodothyronine (FT3; $4.68 \mathrm{pg} / \mathrm{dl}$ [normal, $2.3-$ $5.1 \mathrm{pg} / \mathrm{ml}]$ ) and thyroid-stimulating hormone (TSH; $0.951 \mathrm{uU} / \mathrm{ml}$ [normal, 0.36-7.6 uU/ml]) concentrations were all within normal limits. $25(\mathrm{OH})$ Vitamin D was $42 \mathrm{ng} / \mathrm{ml}$. All other clinical and laboratory examinations were normal.

Neck ultrasound (US) showed multiple, solid, hypo-echoic nodules of the thyroid gland. The largest nodule measured $12 \times 14 \times 12 \mathrm{~mm}$, was located at the inferior pole of the left lobe, and included a cystic area and macro-calcifications. Another nodule, measuring 11x10x9 mm, was localized to the junction of the left lobe with the isthmus and included punctate calcifications. Fine needle aspiration cytology (FNAC) of both nodules yielded benign results.

US also revealed a nodule on the inferior posterior of the left lobe of the thyroid gland, measuring $1,5 \times 2,5 \times 1,5 \mathrm{~cm}$. This nodule was suspected as parathyroid adenoma. Immediate and late post injection Tc-99m MIBI scans showed no uptake, consistent with a parathyroid adenoma.

Renal function tests were within normal limits, including a serum urea concentration of $40.7 \mathrm{mg} / \mathrm{dl}$ (normal, $19-50 \mathrm{mg} / \mathrm{dl}$ ), a serum creatinine concentration of $0.78 \mathrm{mg} / \mathrm{dl}$ (normal, $0.5-1.1 \mathrm{mg} / \mathrm{dl}$ ) and a glomerular filtration rate of $111 \mathrm{~mL} / \mathrm{min} / 1.73 \mathrm{~m}^{2}$. US showed no evidence of nephrolithiasis. Bone mineral densitometry indicated osteopenia.

Due to suspected parathyroid carcinoma, the patient was referred for surgery, consisting of parathyroidectomy and left lobectomy. Total thyroidectomy was not planned because FNAC showed that the thyroid nodules were benign. Rather, left lobectomy was performed as a part of unblock resection of the parathyroid operation. Four gland exploration was performed during operation as routinely done in parathyroid carcinoma cases. Therapeutic central/lateral neck dissection was not performed because there was no suspicious lymph nodes. Post-surgical monitoring of the patient for hungry bone syndrome was negative. Her post-operative albumin-corrected serum $\mathrm{Ca}$ concentration was $7.8 \mathrm{mg} / \mathrm{dl}$, serum P was $4.3 \mathrm{mg} / \mathrm{dl}$ and $\mathrm{iPTH}$ was $56 \mathrm{pg} / \mathrm{dl}$.

Histopathology of the resected specimen showed a parathyroid carcinoma in the left lower parathyroid gland and a co-occurring papillary carcinoma of the left lower lobe of the thyroid gland. The parathyroid tumor measured 1,4 x 2,5 cm, showed invasion of the capsule and adjacent tissue and had positive surgical margins (Figure 1a-c). Vascular invasion and abnormal mitoses were observed. Ki67 proliferation index was $5 \%$. The TPC was $5 \mathrm{~mm}$ in diameter (occult) and capsule invasion was positive (Figure 1d). This tumor was classified as T3NxMx. The patient therefore underwent total thyroidectomy and central lymph node dissection. Another focus of papillary carcinoma, measuring 2 $\mathrm{mm}$ in diameter, was detected on the right lobe. Lymph nodes were negative for the carcinoma. Due to capsule invasion of the TPC, the patient was treated with radioactive iodine therapy.

The patient was screened for metastasis of the PC by thoracic and abdominal magnetic resonance imaging (MRI) and bone scintigraphy. No metastasis was detected. Follow-up includes periodic measurements of serum PTH and albumin-corrected Ca concentrations.

\section{DiscuSSION}

Co-occurring thyroid pathologies are common in patients with PHPT, with rates reported to range from $17 \%$ to $84 \%$ in patients undergoing neck exploration for PHPT [3-9]. In contrast, the synchronous occurrence of parathyroid and differentiated thyroid carcinoma is a rare situation. A search of the literature found only six previous reports of synchronous parathyroid and non-medullary thyroid carcinoma [10-15].

The etiology of PC is unknown. Predisposing factors may include exposure to radiation, prolonged secondary hyperparathyroidism, adenoma or a hyperplastic parathyroid gland. Mutations in the HRPT2, or CDC73, gene have been linked to the pathogenesis of PC [16]. A retrospective review of 12,037 patients with parathyroid adenoma and 83 with parathyroid cancer in the Swedish Family Cancer Database from 1958 to 2008 analyzed the risk of developing other malignancies. The risk of parathyroid cancer was found to be [elevated in patients previously diagnosed with thyroid cancer or parathyroid adenoma. The association with parathyroid adenoma may be attributed to HRPT2 gene mutations. However, the factors associated with the elevated risk of parathyroid cancer after thyroid cancer remains unknown. 
The incidence of PHPT has increased since measurements of serum $\mathrm{Ca}$ became a routine part of clinical practice. PC is a rare cause of PHPT, accounting for less than $1 \%$ of such cases [2]. Because both carcinoma and adenoma of the parathyroid may present with similar clinical and laboratory findings, diagnosis is difficult to establish. Unlike benign parathyroid disease, approximately half of patients with PC present with a palpable neck mass. Our patient had a nontender, palpable mass on the left side of her neck. US also showed the presence of a parathyroid adenoma, measuring $1,5 \times 2,5 \times 1,5$ $\mathrm{cm}$. Guidelines indicate that parathyroid lesions $>3 \mathrm{~cm}$ in patients with serum Ca concentrations $>3$ $\mathrm{mmol} / \mathrm{l}(>12 \mathrm{mg} / \mathrm{dl})$ should be suspected of being PC [17]. Serum Ca concentrations in patients with PC range from 14.6 to $15.9 \mathrm{mg} / \mathrm{dL}$ (3.7 to $4.0 \mathrm{mmol} / \mathrm{L}$ ), with up to $75 \%$ having albumin-corrected $\mathrm{Ca}$ concentrations $>14 \mathrm{mg} / \mathrm{dL}(>3.5 \mathrm{mmol} / \mathrm{L})$ [18]. The serum Ca concentration of the patient described here was $12.4 \mathrm{mg} / \mathrm{dL}(>3 \mathrm{mmol} / \mathrm{L})$. Suspicion of $\mathrm{PC}$ is important in determining the surgical approach, since more aggressive surgical excision has been associated with a higher cure rate [17].

Tc-99m MIBI is currently utilized for parathyroid localization. Most false-negative results are due to small lesion size. Another reason may be related to cellular function [19]. Parathyroid tissue expressing P-glycoprotein or multi-drug resistance related protein (MRP) does not accumulate MIBI [20]. Mitochondria-rich oxyphil cells show greater uptake of MIBI; thus, parathyroid glands with fewer oxyphil cells may yield false negative results [21]. Thus, negative results on MIBI scans do not exclude parathyroid lesions if there is clinical suspicion.

Our patient had two nodules on the left lobe of her thyroid, with FNAC showing that both were benign. The false negative rate on FNAC is about 5\% [22]; thus, thyroid nodules yielding negative results require follow-up in patients who have undergone only parathyroidectomy. The question came to mind is if the parathyroid adenoma targeted for FNAC? Measuring PTH in wash fluid after FNAC would be useful in a presumed parathyroid adenoma.

PC patients are more likely to have metabolic bone (34 to 73\%) and renal disease (32 to 70\%) compared to those with benign adenomas [23]. Our patient did not have any renal or metabolic bone disease complications. Osteoporosis was not presented, despite it is highly probable in a post menopausal woman with hyperparathyroidism. This was probably due to patient's early stage.

In conclusion, we have presented a rare case of synchronous parathyroid and thyroid papillary carcinoma. Coexistent thyroid pathologies including differentiated cancers may occur frequently in patients with parathyroid lesions. Thus, the thyroid should be evaluated in patients with PHPT.

\section{REFERENCES}

[1] Lee PK, Jarosek SL, Virnig BA, Evasovich M, Tuttle TM. Trends in the incidence and treatment of parathyroid cancer in the United States. Cancer. 109, 9 (2007).

[2] Ruda JM, Hollenbeak CS, Stack BC Jr. A systematic review of the diagnosis and treatment of primary hyperparathyroidism from 1995 to 2003. Otolaryngol Head Neck Surg.132, 3 (2005).

[3] Bentrem DJ, Angelos P, Talamonti MS, Nayar R. Is preoperative investigation of the thyroid justified in patients undergoing parathyroidectomy for hyperparathyroidism? Thyroid. 12, 12 (2002).

[4] Strichartz SD, Giuliano AE. The operative management of coexisting thyroid and parathyroid disease. Arch Surg. 125, 10 (1990).

[5] Monroe DP, Edeiken-Monroe BS, Lee JE, Evans DB, Perrier ND. Impact of preoperative thyroid ultrasonography on the surgical management of primary hyperparathyroidism. Br J Surg. 95, 8 (2008).

[6] Kösem M, Algün E, Kotan C, Harman M, Oztürk M. Coexistent thyroid pathologies and high rate of papillary cancer in patients with primary hyperparathyroidism: controversies about minimal invasive parathyroid surgery. Acta Chir Belg. 104, 5(2004).

[7] Gul K, Ozdemir D, Korukluoglu B, Ersoy PE, Aydin R, Ugras SN, Ersoy R, Cakir B. Preoperative and postoperative evaluation of thyroid disease in patients undergoing surgical treatment of primary hyperparathyroidism. Endocr Pract. 16, 1(2010).

[8] Krause UC, Friedrich JH, Olbricht T, Metz K. Association of primary hyperparathyroidism and non-medullary thyroid cancer. Eur J Surg. 162, 9 (1996).

[9] Leitha T, Staudenherz A. Concomitant Hyperparathyroidism and Nonmedullary Thyroid Cancer, with a Review of the Literature. Clinical Nuclear Medicine. 28, ( 2003). 
[10] Kurita S, Mihashi S, Hirano M, Nakashima T, Tanimura A. Hyperfunctioning parathyroid carcinoma combined with papillary carcinoma of the thyroid gland-report of a case. Nippon Gan Chiryo Gakkai Shi. 14, 7(1979).

[11] Savli H, Sevinc A, Sari R, Ozen S, Buyukberber S, Ertas E. Occult parathyroid carcinoma in a patient with papillary thyroid carcinoma and Hashimoto's thyroiditis. J Endocrinol Invest. 24, 1(2001).

[12] Schoretsanitis G, Melissas J, Kafousi M, Karkavitsas N, Tsiftsis DD. Synchronous parathyroid and papillary thyroid carcinoma: a case report. Am J Otolaryngol. 23, 6 (2002).

[13] Lin SD, Tu ST, Hsu SR, Chang JH, Yang KT, Yang LH. Synchronous Parathyroid and Papillary Thyroid Carcinoma. J Chin Med Assoc. 68, 2 (2005).

[14] Chaychi L, Belbruno K, Golding A, Memoli V. Unusual manifestation of parathyroid carcinoma in the setting of papillary thyroid cancer. Endocr Pract. 16, 4 (2010).

[15] Goldfarb M, O’Neal P, Shih JL, Hartzband P, Connolly J, Hasselgren PO. Synchronous parathyroid carcinoma, parathyroid adenoma and papillary thyroid carcinoma in a patient with severe and longstanding hyperparathyroidism. Endocr Pract. 15, 5 (2009).

[16] Abdelgadir Adam M, Untch BR, Olson JA Jr. Parathyroid carcinoma: current understanding and new insights into gene expression and intraoperative parathyroid hormone kinetics. Oncologist. 15, 1 (2010).

[17] Schulte KM, Talat N. Diagnosis and management of parathyroid cancer. Nat Rev Endocrinol. 8 (2012).

[18] Talat N, Schulte KM. Clinical presentation, staging and long-term evolution of parathyroid cancer. Ann Surg Oncol. 17 (2010).

[19] Palestro CJ, Tomas MB, Tronco GG. Radionuclide imaging of the parathyroid glands. Semin Nucl Med. 35 (2005).

[20] Sun SS, Shiau YC, Lin CC, Kao A, Lee CC. Correlation between P-glycoprotein (P-gp) expression in parathyroid and Tc-99m MIBI parathyroid image findings. Nucl Med Biol. 28 (2001).

[21] Melloul M, Paz A, Koren R, Cytron S, Feinmesser R, Gal R. 99mTc-MIBI scintigraphy of parathyroid adenomas and its relation to tumour size and oxyphil cell abundance. Eur $\mathrm{J}$ Nucl Med. 28 (2001).

[22] Ylagan LR, Farkas T, Dehner LP. Fine needle aspiration of the thyroid: a cytohistologic correlation and study of discrepant cases. Thyroid. 14, 35 (2004).

[23] Iihara M, Okamoto T, Suzuki R, Kawamata A, Nishikawa T, Kobayashi M, Obara T. Functional parathyroid carcinoma: Long-term treatment outcome and risk factor analysis. Surgery. 142 (2007). 